\title{
БОЙОВИЙ СТРЕС \\ ТА РЕЗУЛЬТАТИ ЙОГО ЕМПІРИЧНОГО ДОСЛІДЖЕННЯ
}

УДК: 159.944.4.9.07-057.36 (045)

\section{Блінов Олег Анатолійович}

Кандидат психологічних наук, доцент, доцент кафедри сочіальних технологій Національного авіаційного університету, науковий кореспондент лабораторії психологї навчання імені I. О. Синииі Інституту психологї імені Г. С. Костюка Національної академї̈ педагогічних наук України, м. Київ (Украӥна)

\begin{abstract}
Анотація. У статті охарактеризований бойовий стрес та наведені наслідки його дії. Проведений історичний огляд наукових підходів щцодо вивчення категорї «бойовий стрес». Представлено результати емпіричного дослідження бойового стресу та посттравматичного стресового розладу. Проаналізована динаміка показників бойового стресу залежно від терміну перебування в зоні бойових дій. Визначені причини та розглянуті особливості проявів переживань військовослужбовиів в результаті дї травматичного стресу за допомогою опитувальника скринінгу посттравматичного стресового розладу (ОС ПТСР) і опитувальника бойового стресу Блінова О. А. (ОБСБ). Розглянути кореляційні зв'язки між показниками бойового стресу опитувальників.
\end{abstract}

Ключові слова: військовослужбовиі, бойовий стрес, посттравматичний стресовий розлад, поранення, контузіі.

Постановка проблеми та її зв'язок 3 важливими практичними завданнями. Бойовий стрес 3'являється у людини в екстремальних умовах діяльності, яка супроводжується дією потужних зовнішніх і внутрішніх стресфакторів. Вони несуть загрозу життю людини, негативно впливають на стан іï здоров'я, знижують ефективність діяльності або приводять до її зриву. Бойовий стрес може приводити як до гострих психологічних реакцій на вплив стрес-факторів так і розвитку стресових розладів [1].

Вони характеризуються у бійців високим рівнем тривожності, агресивності, конфліктності, пониженням працездатності, сприяють поширенню дезадаптації, депресивних станів, суїцидів, алкоголізму, наркоманії, асоціальної поведінки та ін.

За статистичними даними відомо, що близько $80 \%$ військовослужбовців, які прий- 
мали участь в бойових діях під час проведення АТО, отримували бойовий стрес, який в подальшому трансформувався приблизно в 25\% ПТСР різного ступеню виразності. 98\% 3 учасників бойових дій потребують кваліфікованої підтримки і допомоги внаслідок дії бойових стрес-факторів. 20\% учасників бойових дій мають підпорогові ознаки ПТСР (реакції дезадаптації). 27\% бійців мають неповні клінічні прояви ПТСР, які призводять до щоденних негативних наслідків. Скривають психічні проблеми та ніколи не отримували відповідної допомоги $-75 \%$ комбатантів. Соромляться або заважають виявленню психічних проблем - 93\% військовослужбовців. 13 років може минути між часом виникнення ПТСР та отриманням комбатантами психологопсихіатричної допомоги [11].

У зв'язку зі значною актуальністю проблеми бойового стресу та його наслідків, як для комбатантів так і для суспільства, вона потребує уважного вивчення і дослідження причин, механізмів впливу. Умови сьогодення вимагають організації масштабної психологічної та психотерапевтичної роботи фахівців, організації системи психологічного захисту від бойового стресу [4].

Аналіз останніх досліджень і публікацій. Наслідки війн і збройних конфліктів вимагають вивчення категорії «бойовий стрес».

Бойовий стрес $€$ об'єктом вивчення фахівців вже тривалий час. Наприклад на початку XX століття він був відомий під назвою «меланхолія без марення» (М. Шайкевич, 1905), «невростенічний психоз», «нервове виснаження» (П. Автократов, 1906, 1911; О. Озерецький, 1906), «душевні рани отримані в бою» (Г. Шумков, 1913) та ін. [7].

Психічним розладам у період Першої світової війни вітчизняні науковці дали назви «воєнний невроз» (В. Бєхтєрєв, 1914), «бойові та окопні психічні розлади» (О. Гервер, 1915), «істерічний психоз» (С. Давиденков, 1915, 1916), «травматичний невроз» (Б. Грейнденберг, 1918) та ін.

Дослідження категорії «бойовий стрес» фахівцями Радянського Союзу проводилося виключно в межах психіатрії. 3 цих позицій розглядалися проблеми викликані бойовою психічною травмою. Вкладом фахівців у розвиток уявлень про бойовий стрес поява понять «емоційний шок», «емоційний невроз» (М. Аствацатуров, 1936), «тимогенії» (В. Гіляровський, 1944) та ін.

Війна в Афганістані радянських воїнів та зникнення разом 3 СРСР партійнополітичного апарату дало можливість розглядати проблеми бойового стресу не тільки 3 позицій психіатрії (використання фармакологічних препаратів, медичної психотерапії), загальнопсихологічного, психофізіологічного, педагогічного методів вирішення питань бойового стресу. 3'явилися можливості вивчати світ психічних явищ у військовослужбовців в результаті дії бойового стресу без ідеологічнобюрократичних обмежень, за допомогою пси- 
хологічних методів і методик, проводити психологічну психотерапію (В. Знаков, 1990; Р. Абдурахманов, 1992; В. Попов, 1994; Л. Кітаєв-Смик, 1995, 2001) та ін.

В умовах сучасності, в межах психологічного наукового напрямку досліджуються різні аспекти наслідків бойового стресу, як результату діяльності в екстремальних умоваx.

Так, наприклад, розглядалися питання психічного стресу в учасників бойових дій та його суб'єктивного переживання (А. М. Резник, 2008), травматичного стресу та особистісних особливостей учасників бойових дій (Н. В. Якушкін, 2009), особливості смислової сфери військовослужбовців, які пережили бойовий стрес (А. А. Утюганов, 2011), психологічні особливості особистості військовослужбовця - учасника бойових дій (А. В. Срмолаєва, 2013), соціально-психологічні детермінанти виникнення бойового стресу у військовослужбовців - учасників антитерористичної операції (К. О. Кравченко, О. В. Тімченко, Ю. М. Широбоков, 2017) та ін.

У поглядах зарубіжних дослідників трансформація категорії «бойовий стрес» відбувалася наступним чином: «ностальгія» (Д. Хофер, 1688; Верховитц, 1793 та ін.), «пальпітація» (А. Маерс, 1856), «виснаження серцевого м'яза» (Г. Хартшон, 1865), «солдатське серце» (Я. Да Коста, 1871), «травматичний невроз» (Г. Оппенгейм, 1889), «контузія», «артилерійський шок» (Ч. Маєрс,
Т. Салмон, 1917), «військовий невроз» (3. Фрейд, 1915), «військовий стрес» (Р. Лаофер, 1935), «сукупність фізіологічного, емоційного та соціального стресу» (Г. Шпігель, Р. Грінкер, 1945), «бойова травма», «бойовий шок» (Д. Гудвін, С. Бентлі, 1955), «психічна травма» (К. Кріс, В. Де Фацио, С Ферст, А. Солніт, 1957 та ін.), «бойове виснаження» (Н. Камерон, 1963), «концепція синдромів стресової реакції» (М. Горовиць, 1976), «інтеракціоністська модель травматизації (Б. Грін, Д. Вільсон, Л. Лінді, 1986) та ін. [13].

Таким чином, за думкою зарубіжних фахівців, бойовий стрес під його різними назвами є невід'ємним компонентом психотравматизації військовослужбовця в умовах бойової діяльності.

За нашою думкою, в сучасних умовах категорія «бойовий стрес» розглядається провідними закордонними фахівцями 3 двох позицій.

В Російській Федерації відбулося об'єднання наукової думки військових психіатрів і психологів на феноменологію бойового стресу. Так у підручнику «Військова психіатрія» під ред. С. В. Литвинцева і В. К. Шамрея (видання 2001 року) [5], а також під керівництвом С. В. Литвинцева, Е. В. Снедкова, А. М. Резника «Бойова психічна травма» (видання 2005 року) під бойовим стресом розуміється багаторівневий адаптаційний процес в умовах бойової обстановки, що супрово- 
джується напругою механізмів реактивної саморегуляції і закріпленням специфічних пристосувальних психофізіологічних змін [9]. Аналогічної точки зору дотримується провідний військовий психолог О. Г. Караяни (2016) [6].

Іншої точки зору дотримуються фахівці НАТО. За їх думкою, бойовим стресом (BSC) $\epsilon$ індивідуальне відображення бойової стресової реакції [14].

За думкою українських фахівців (I. I. Приходько, 2017), бойовим стресом $\epsilon$ «процес впливу факторів бойової обстановки на психіку військовослужбовця, який супроводжується зниженням рівня психологічної безпеки особистості та появою неспецифічних доклінічних психологічних проявів, які у сукупності складають поняття «бойова психологічна травматизація особистості» або досягають специфічних нозоологічних проявів психічних розладів, об'єднаних у категорію «бойова психічна травма» [10].

Під бойовим стресом К. О. Кравченко, О. В. Тімченко, Ю. М. Широбоков (2017) розуміють «переживання, які виникають у військовослужбовців при опосередкованому, чи безпосередньому впливі на нього стресфакторів бойової діяльності та проявляються у вигляді емоційних, інтелектуальних, фізичних та поведінкових реакцій [7, с. 39].

Усе зазначене вище дозволяє нам висказати власну точку зору, згідно якої бойовим стресом $\epsilon$ «реакція психіки на загрозу життя та здоров'я у вигляді процесу пережи- вань психічних станів за етапами адаптації 3 використанням потенціалу іï ресурсів».

Ми вважаємо, що психологічна ресурсна база людини є основою оптимізації психічних станів військовослужбовця і психологічної адаптації в результаті дії травматичного стресу.

Методологічною основою цього положення, по-перше, є концепція А. Кардінера про невротичні розлади у військових, які були спричинені війною. Вона була викладена в 1941 році в масштабному клінічному та теоретичному дослідженні «Травматичні неврози війни», де він зазначав, що психологічні проблеми ветеранів «...обумовлені зменшенням внутрішніх ресурсів, тому зовнішній світ ними починає сприйматися як ворожий». Це визначення дає можливість припустити, що саме «бойовий стрес» $\epsilon$ причиною зменшення внутрішніх ресурсів військовослужбовця [15].

А. Кардінер також розглядав відстрочені реакції у ветеранів 3 точки зору концепції адаптації. 3 них він виділяв п'ять головних: фіксація на травмі, типові сни, зниження загального рівня психічної діяльності, дратівливість, схильність до вибухових агресивних реакцій.

На думку А. Кардінера, адаптаційні можливості військовослужбовця можуть давати змогу спрогнозувати перебіг у нього «бойового стресу» та подальше його ускладнення. Таким чином, А. Кардінером була виділена адаптаційна складова у структурі су- 
часного поняття «бойовий стрес» [16].

По-друге, нами використана багатовимірна модель психологічного виживання людини після сильного стресу BASIC Ph M. Лаада. Згідно його концепції, у кожної людини існуе 6 основних каналів, кожен 3 яких «допомагає» вийти з кризової ситуації, а саме: віра (вelief and values), емоції (affect and emotion), спілкування (social), уява (imagination), розсудливість (cognition and thought), фізична активність (physiology and activities) [12].

Результати наших досліджень свідчать про значний рівень психотравматизації військовослужбовців у наслідок дії бойового стресу. Так, мають підпорогові ознаки ПТСР (реакції дезадаптації) $11 \%$ військовослужбовців, які приймали участь у бойових діях, неповні клінічні прояви ПТСР діагностовано у 8\% військовослужбовців, ймовірність ПТСР встановлена у $19 \%$ бійців (разом $38 \%$ ).

Серед поранених військових підпорогові ознаки ПТСР (реакції дезадаптації) мають $12 \%$ комбатантів, неповні клінічні прояви ПТСР - 13\% осіб, ймовірність ПТСР встановлена у $46 \%$ бійців (разом 71\%).

Виділення невирішених раніше частин загальної проблеми, якій присвячусться стаття. Результати емпіричного дослідження бойового стресу дозволяють 3 нових позицій розглянути прояви бойового стресу та його динаміку протягом більш ніж дворічного терміну.
У дослідженні бойового стресу використовується психодіагностичний інструментарій у вигляді опитувальника бойового стресу Блінова О. А. (ОБСБ). Внутрішня узгодженість субшкал опитувальника за коефіцієнтом альфа Л. Кронбаха (KR) має наступні рівні: ГСР ПТСР - 0,71, РБ - 0,59, ФБЕВ - 0,706, ФOEB - 0,38.

Також був використаний опитувальник скринінгу посттравматичного стресового розладу (ОС ПТСР). Загальний коефіцієнт внутрішньої узгодженості показників опитувальника за альфою Л. Кронбаха (KR) - 0,65.

Отримані за допомогою цього психологічного інструментарію результати дозволяють уявити поширеність ПТСР за віковими періодами людини, залежно від тривалості перебування в зоні бойових дій.

Мета статті полягає у розкритті особливостей прояву бойового стресу в військовослужбовців учасників бойових дій, що потребує з'ясування зв'язків між гострими стресовими розладами і посттравматичними стресовими розладами; ресурсним потенціалом особистості; рівнем впливу стрес-факторів, що безпосередньо емоційно впливають на особистість військовослужбовця, а також рівнем впливу стрес-факторів, що опосередковано емоційно впливають на особистість бійця.

Виклад основного матеріалу дослідження. Нами було проведено емпіричне дослідження проявів бойового стресу.

У дослідженні взяли участь 307 війсь- 
ковослужбовців, які пройшли процедуру психодіагностичного обстеження за опитувальником бойового стресу Блінова О. А. (ОБСБ). Серед них учасниками бойових дій було 166 чоловік, 141 військовослужбовець був без досвіду участі в бойових діях [2].

Також 303 військовослужбовці були опитані за допомогою опитувальника скринінгу посттравматичного стресового розладу (OC ПТСР). Серед них учасниками бойових дій було 168 чоловік, у 135 військовослужбовців досвід участі в бойових діях був відсутній [3].

Серед всіх осіб, які пройшли психодіагностичне обстеження 211 військових були учасниками обох опитувань.

За віком учасники дослідження були
Розподіл учасників за вказаними групами відображено у Таблиці 1.

Перше, що нас цікавило, чи існує вікова залежність, пов'язана 3 переживанням бойового стресу. Ми порівнювали середні за віковими групами показники опитувальників ОС ПТСР і ОБСБ (див. Табл. 2).

За обома методиками виявлено чітку зростаючу тенденцію - чим людина старша, тим сильніше вона переживає бойовий стрес. При чому між юнаками та особами старшого віку така різниця $€$ статистично значуща (також в обох методиках, рівень значущості $\alpha=0,01$, за критерієм Ст’юдента).

Так, за показником ОС ПТСР, особи від 20 до 31 року мають 3,16 балів. Цей рівень Таблиця 1.

Розподіл учасників бойових дій за віковими групами (у \%)

\begin{tabular}{|l|c|c|c|c|c|c|}
\hline \multicolumn{1}{|c|}{ Вікова група } & $\begin{array}{c}\text { Кількість } \\
\text { ОС ПТСР }\end{array}$ & $\begin{array}{c}\text { Учас- } \\
\text { бокий } \\
\text { дій }\end{array}$ & $\begin{array}{c}\text { Не брали } \\
\text { участь }\end{array}$ & $\begin{array}{c}\text { Кількість } \\
\text { ОБСБ }\end{array}$ & $\begin{array}{c}\text { Учас- } \\
\text { ники бо- } \\
\text { йових дій }\end{array}$ & $\begin{array}{c}\text { Не брали } \\
\text { участь }\end{array}$ \\
\hline до 20 років & 31,0 & - & 69,6 & 31,6 & - & 68,8 \\
\hline $\begin{array}{l}\text { від 21 до 30 ро- } \\
\text { ків }\end{array}$ & 32,0 & 42,4 & 19,3 & 32,2 & 42,9 & 19,9 \\
\hline $\begin{array}{l}\text { від 31 до 50 ро- } \\
\text { ків }\end{array}$ & 33,7 & 53,0 & 9,6 & 33,3 & 52,3 & 10,6 \\
\hline старші 50 років & 3.3 & 4,6 & 1,5 & 2,9 & 4,8 & 0,7 \\
\hline Всього (за 100\%) & 303 & 168 & 135 & 307 & 166 & 141 \\
\hline
\end{tabular}

об'єднані у 4 вікові групи: до 20 років, від 21 до 30 років, від 31 до 50 років й тих, кому за 50. Дані групи, певною мірою, відповідають життєвим періодам соціально-психологічного розвитку дорослої людини - юнацький вік, зрілість, люди старшого віку [8]. перевищує на 1,15 балів аналогічний показник у військових до 20 років. За показником ОБСБ у аналогічних категорій військовослужбовців різниця складає 5,97 балів. Поясненням причини існуючих розбіжностей (засвідчених на статистичному рівні) між віковими групами $\epsilon$ 
Віковий розподіл показників бойового стресу (у балах)

\begin{tabular}{|c|c|c|c|c|c|c|}
\hline Вікова група & $\begin{array}{c}\text { ОС } \\
\text { ПТСР }\end{array}$ & ОБСБ & $\begin{array}{c}\text { ГСР } \\
\text { ПТС }\end{array}$ & РБ & ФБЕВ & ФОЕВ \\
\hline до 20 років & $2,01 \pm 1,24$ & $59,43 \pm 10,75$ & $16,70 \pm 4,37$ & $14,47 \pm 4,17$ & $15,08 \pm 3,11$ & $13,18 \pm 3,40$ \\
\hline від 21 до 30 років & $3,16^{\otimes \otimes} \pm 1,83$ & $65,40^{\otimes \otimes} \pm 12,60$ & $19,93 \pm 5,39$ & $16,22 \pm 3,65$ & $15,02 \pm 3,95$ & $14,22 \pm 3,63$ \\
\hline від 31 до 50 років & $3,27 \pm 1,86$ & $67,72 \pm 13,15$ & $20,80 \pm 6,10$ & $17,10 \pm 4,63$ & $15,01 \pm 3,91$ & $14,81 \pm 3,39$ \\
\hline старші 50 років & $3,56 \pm 1,33$ & $72,33 \pm 11,71$ & $21,56 \pm 2,87$ & $18,11 \pm 4,89$ & $15,89 \pm 3,75$ & $16,78 \pm 2,90$ \\
\hline
\end{tabular}

Примімка:

ГСР_ПТСР - Субшкала № 1 опитувальника ОБСБ. Для скринінгового обстеження гострих стресових розладів (ГСР) і посттравматичних стресових розладів (ПТСР).

РБ - Субшкала № 2 опитувальника ОБСБ. Ресурсний блок (РБ).

ФБЕВ - Субшкала № 3. Для визначення впливу стрес-факторів, щчо безпосередньо емочійно впливають на особистість військовослужбовия (ФБЕВ).

ФОЕВ - Субшкала № 4. Для визначення впливу стрес-факторів, щуо опосередковано емоційно впливають на особистість військовослужбовия (ФОЕВ).

${ }^{\otimes}$ - достовірність відмінностей між групами при $P<0,01$.

те, що особи від 20 до 31 року приймали участь в бойових діях, а військовослужбовці до 20 років - ні.

Ми звернули увагу на два моменти. Поперше, близькість значень показника ОБСБ та його складових (гострих стресових розладів, ресурсного блоку й факторів емоційного впливу) у респондентів груп «зрілості».

По-друге, показники факторів ФБЕВ i ФОЕВ мають два інтервали прояву, до і після 50 років.

Ми також припускали, що можуть існувати вікові відмінності серед учасників бойових дій й тих військовослужбовців, хто в бойових діях участі не брав. Дане припущення підтвердилося (див. Табл. 3). Звідси можна зробити висновок, що фактор участі в бойових діях $є$ суттєвим щодо вікової специфіки переживання бойового стресу.
Також ми звернули увагу на три моменти.

У першому випадку за показниками ОС ПТСР в учасників бойових дій встановлений вищий (у середньому на 1 бал) рівень переживань бойового стресу за всіма віковими категоріями ніж у тих військовослужбовців хто не приймав у них участі. За показником ГСР_ПТСР ця розбіжність значніша - від 2 до 4 балів за віковими періодами.

Другий момент, на який ми звернули увагу. Спостерігається більш високий рівень переживань у військовослужбовців, які не приймали участь в бойових діях блоку показників ФБЕВ і ФОЕВ.

Третім моментом є отримані рівні показників РБ. Встановлено зростання рівня цього показника за віковими періодами військовослужбовців. У бійців старших за 50 років 


\section{Віковий розподіл показників бойового стресу за участю в бойових діях (у балах)}

\begin{tabular}{|c|l|c|c|c|c|c|c|}
\hline $\begin{array}{c}\text { Участь } \\
\text { в бойо- } \\
\text { вих діях }\end{array}$ & Вікова група & $\begin{array}{c}\text { ОС } \\
\text { ПТСР }\end{array}$ & ОБСБ & $\begin{array}{c}\text { ГСР } \\
\text { ПТС }\end{array}$ & РБ & ФБЕВ & ФОЕВ \\
\hline \multirow{4}{*}{ так } & від 21 до 30 років & $3,27 \pm 1,81$ & $65,89 \pm 12,12$ & $20,67 \pm 5,35$ & $16,30 \pm 3,83$ & $14,86 \pm 3,69$ & $14,06 \pm 3,48$ \\
\cline { 2 - 8 } & від 31 до 50 років & $3,33 \pm 1,82$ & $68,13 \pm 13,65$ & $21,44 \pm 6,22$ & $16,88 \pm 4,52$ & $14,96 \pm 3,97$ & $14,85 \pm 3,35$ \\
\cline { 2 - 8 } & старші 50 років & $3,50 \pm 1,35$ & $72,25 \pm 12,42$ & $22,00 \pm 2,74$ & $18,50 \pm 5,05$ & $15,50 \pm 3,81$ & $16,25 \pm 2,63$ \\
\hline \multirow{4}{*}{ ні } & до 20 років & $2,01 \pm 1,24$ & $59,22 \pm 10,68$ & $16,56 \pm 4,35$ & $14,44 \pm 4,14$ & $15,09 \pm 3,15$ & $13,12 \pm 3,38$ \\
\cline { 2 - 8 } & від 21 до 30 років & $2,88 \pm 1,88$ & $64,18 \pm 13,67$ & $18,07 \pm 4,85$ & $16,04 \pm 3,15$ & $15,43 \pm 4,51$ & $14,64 \pm 3,96$ \\
\cline { 2 - 8 } & від 31 до 50 років & $2,92 \pm 2,14$ & $65,40 \pm 9,52$ & $17,20 \pm 3,69$ & $18,33 \pm 5,06$ & $15,27 \pm 3,57$ & $14,60 \pm 3,59$ \\
\cline { 2 - 8 } & старші 50 років & 2,50 & 73,00 & 18,00 & 15,00 & 19,00 & 21,00 \\
\hline
\end{tabular}

він складає 18,5 балів, що на 3,5 балів перебільшує рівень у бійців, які не приймали участь

СБ бачимо, що між виділеними групами існує в бойових діях.

достатньо суттєва різниця. Але статистична

Наступним питанням було 3'ясування значущість була віднайдена лише у випадку показників ОС ПТСР і гострого стресового відмінностей переживання бойового стресу в розладу (рівень значущості $\alpha=0,05$, за критеучасників бойових дій в цілому. Середні зна-

Таблиия 4.

Показники переживання бойового стресу учасниками і неучасниками бойових дій (у балах)

\begin{tabular}{|c|c|c|c|c|c|c|}
\hline $\begin{array}{c}\text { Участь в бойо- } \\
\text { вих діях }\end{array}$ & $\begin{array}{c}\text { ОС } \\
\text { ПТСР }\end{array}$ & ОБСБ & $\begin{array}{c}\text { ГСР } \\
\text { ПТС }\end{array}$ & РБ & ФБЕВ & ФОЕВ \\
\hline ні & $2,27 \pm 1,09$ & $60,96 \pm 11,51$ & $16,94 \pm 4,42$ & $15,18 \pm 4,25$ & $15,21 \pm 3,51$ & $13,64 \pm 3,64$ \\
\hline так & $3,31^{\otimes} \pm 1,14$ & $67,35 \pm 13,01$ & $21,14^{\otimes_{1}} \pm 5,70$ & $16,69 \pm 4,31$ & $14,94 \pm 3,81$ & $14,58 \pm 3,42$ \\
\hline
\end{tabular}

\section{Примімка:}

${ }^{\otimes}$ - достовірність відмінностей між групами при $P<0,05$.

чення показників наведено у таблиці 4 та Рис. 1.

Отримані результати свідчать, що військовослужбовці, які приймали участь в бойових діях мають вищий рівень переживань ніж ті, хто не приймав в них участі (крім Субшкали № 4 ОБСБ - ФБЕВ).

За обома методиками ОС ПТСР та ОБ- рієм Ст'юдента).

Так, за показником ОС ПТСР військовослужбовці, які приймали участь в бойових діях отримали 3,31 бала, що перевищує на 1,04 бали рівень переживань тих осіб, які в них участь не приймали. За показником ГСР_ПТСР у аналогічних категорій військовослужбовців різниця складає 4,2 бали. 
Поясненням причини існуючих розбіжностей (засвідчених на статистичному рівні) між учасниками бойових дій і тих, хто в них участі не приймав $\epsilon$ те, що переживання бойового стресу в учасників має зовсім інший якісний рівень. Він пов'язаний з дією травматичного стресу на особистість військового, присутністю безпосередньої загрози для життя людини протягом тривалого часу.

Тут варто звернути увагу на параметр ФБЕВ, який є одним з найвищих за зведеними показниками й трохи переважає саме в тих, хто брав участь в бойових діях.

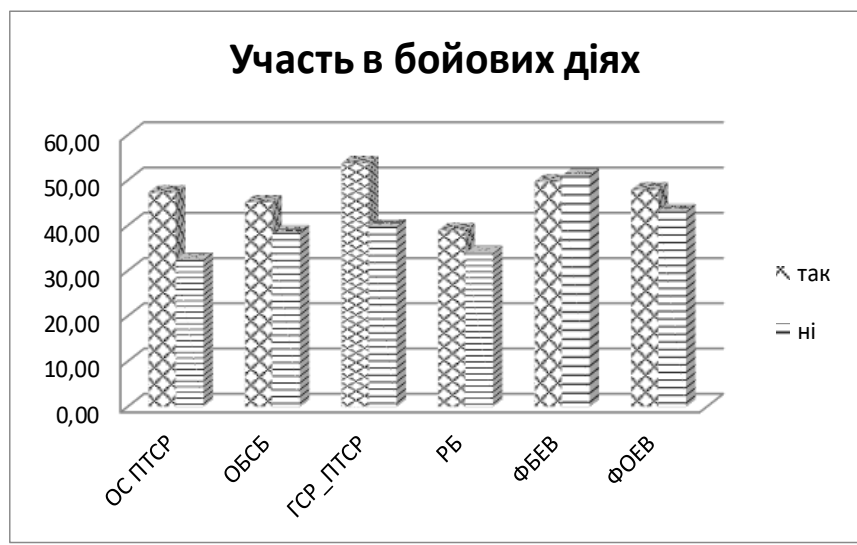

\section{Рис. 1. Зведені показники ОС ПТСР та ОБСБ}

Поясненням тенденції зменшення показника ФБЕВ з 15,21 балу до 14,94 балів є зовсім інша природа стресу у військовослужбовців, які не приймали участь в бойових діях i знаходяться в місцях постійної дислокації військових частин.

Значний рівень переживань викликаний двома основними факторами: особливос- тями бойової підготовки у місцях постійної дислокації військових частин і взаємостосунків у військових колективах.

Для глибшого розуміння отриманих даних ми проаналізували динаміку показників бойового стресу залежно від терміну перебування в зоні бойових дій (див. Табл. 5, а також Рис. 2).

Порівнюючи загальний показник ОБСБ і середній бал ОС ПТСР, звернемо увагу на їх схожість. Найменші значення виявилися в тих, хто за тих чи інших причин не брав участь в бойових діях (61 і 2,3 бали відповідно). Потім до року ці показники поступово, але невпинно зростають до 68,3 й 3,3 балів. Причому, швидкість зростання більш-менш стала.

У наступному періоді зростання обох показників продовжується, проте їх характер змінюється. Якщо динаміка значень ОБСБ уповільнюється до 69,6 балів, то показник ОС ПТСР у період від 1 до 1,5 року зростає різко до 4,24 балів, утворюючи 3 попереднім значенням статистично значущу відмінність (рівень значущості $\alpha=0,05$, за критерієм Ст'юдента).

Це свідчить, що в інтервалі часу від 13 до 18 місяці вплив травматичного стресу на військовослужбовців максимальний. Це обумовлено виснаженням їх психіки від тривалого перебування в бойових умовах, а також подолання психологічного бар'єру до 1 року бойової служби.

В період від 1,5 до 2 років спостеріга- 
Динаміка переживання бойового стресу

Таблиия 5. в учасників бойових дій (у балах)

\begin{tabular}{|c|c|c|c|c|c|c|}
\hline $\begin{array}{c}\text { Тривалість участі в } \\
\text { бойових діях }\end{array}$ & $\begin{array}{c}\text { ОС } \\
\text { ПТСР }\end{array}$ & ОБСБ & $\begin{array}{c}\text { ГСР } \\
\text { ПТС }\end{array}$ & РБ & ФБЕВ & ФОЕВ \\
\hline не брав участі & $2,26 \pm 1,5$ & $61,00 \pm 11,51$ & $17,01 \pm 4,42$ & $15,16 \pm 4,25$ & $15,21 \pm 3,51$ & $13,62 \pm 3,64$ \\
\hline до 3-х міс. & $2,74 \pm 1,53$ & $62,15 \pm 11,22$ & $19,00 \pm 4,33$ & $14,50 \pm 3,07$ & $14,38 \pm 3,85$ & $14,27 \pm 3,26$ \\
\hline від 4-х до 6-и міс. & $2,91 \pm 1,63$ & $65,30 \pm 10,94$ & $19,45 \pm 5,19$ & $16,79 \pm 3,79$ & $14,82 \pm 4,3$ & $14,24 \pm 3,61$ \\
\hline від 7-и до 12-и міс. & $3,28 \pm 1,78$ & $68,31 \pm 13,2$ & $21,46 \pm 6,21$ & $17,54 \pm 4,38$ & $14,87 \pm 3,64$ & $14,44 \pm 3,44$ \\
\hline від 13-и до 18-ти міс. & $4,24^{\otimes} \pm 1,81$ & $69,64 \pm 12,3$ & $22,60 \pm 4,72$ & $17,04 \pm 3,82$ & $14,96 \pm 3,32$ & $15,04 \pm 3,35$ \\
\hline від 19-и до 24-х міс. & $3,93 \pm 1,69$ & $66,25 \pm 10,6$ & $20,83 \pm 5,06$ & $16,17 \pm 3,95$ & $14,42 \pm 2,93$ & $14,83 \pm 2,82$ \\
\hline більше 2-х років & $3,87 \pm 2,26$ & $79,36 \pm 17,56$ & $27,64 \pm 4,92$ & $18,09 \pm 4,53$ & $17,27 \pm 4,43$ & $16,36 \pm 3,67$ \\
\hline
\end{tabular}

\section{Примітка:}

${ }_{-}$- достовірність відмінностей між групами при $P<0,05$.

ється зниження обох показників, причому значення ОБСБ знижується сильніше. Найбільше розходяться показники в останній період - більше 2-х років. В осіб з цієї групи переживання бойового стресу робить найбільший стрибок угору - $з$ 66,3 до 79,4 балів, тоді як значення ОС ПТСР в даних осіб трохи зменшується, проте не досягає рівня періоду від 7 до 12 місяців.

Зазначені вище зміни у рівнях переживань бойового стресу свідчать про наявності критичного рівня на межі в 24 міс. після якого відбуваються руйнівні процеси виснаження, емоційного і професійного вигорання військовослужбовців, розвиток стресових розладів та iн.

Аналізуючи динаміку складових показників бойового стресу, відзначимо схожість траєкторій показників гострого стресового розладу, ресурсного блоку, факторів безпосереднього та опосередкованого емоційного впливу з траєкторією інтегрованої оцінки бойового стресу. Проте, коливання параметру ФОЕВ є найнижчими.

Встановлено, що найвищий рівень потенціалу психологічних ресурсів присутній у бійців, які знаходяться в бойових діях до 3-х

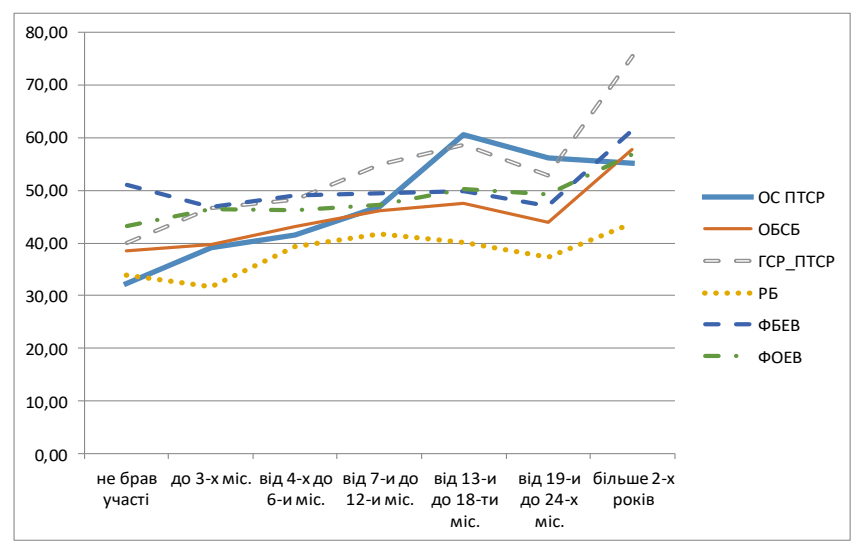

Рис. 2. Динаміка переживання бойового стресу учасниками бойових дій (зведені показники у балах)

міс. Після цього терміну він поступово починає зменшуватися, що сприяє поширенню отримання бойових психічних травм і розвитку стресових розладів. 
Висновки. В результаті емпіричних досліджень встановлено, що мають підпорогові ознаки ПТСР (реакції дезадаптації) 11\% військовослужбовців, які приймали участь в бойових діях, неповні клінічні прояви ПТСР діагностовано у 8\% військовослужбовців, наявність ПТСР встановлена у 19\% бійців.

Серед поранених військових мають підпорогові ознаки ПТСР (реакції дезадаптації) $12 \%$ комбатантів, мають неповні клінічні прояви ПТСР 13\% осіб, ймовірність ПТСР встановлена у $46 \%$ бійців.

Встановлено, що чим людина старша, тим сильніше вона переживає бойовий стрес. Фактор участі в бойових діях є суттєвим щодо вікової специфіки його переживання.

Найвищий рівень потенціалу психологічних ресурсів присутній у бійців, які знаходяться в бойових діях до 3-х міс. Після цього терміну він поступово починає зменшуватися, що сприяє поширенню отримання бойових психічних травм і розвитку стресових розладів.

Критичним рівнем для переживання бойового стресу є межа в 24 міс., після чого відбуваються руйнівні процеси емоційного i професійного вигорання військовослужбовців, їх особистісна деформація, розвиток стресових розладів.

\section{Перспективи подальших розвідок у} даному напрямі полягають у вивченні залежності розвитку бойового стресу в військовос- лужбовців залежно від їх індивідуальнопсихологічних характеристик.

\section{Перелік використаних джерел:}

1. Блінов О. А. Психологія бойової психічної травми : монографія / О. А. Блінов. - К. : Талком, 2016. - 246 с.

2. Блінов $O$. А. Опитувальник бойового стресу Блінова О. А. (ОБСБ) / Психологічний часопис : збірник наукових праць / за ред. С. Д. Максименка. - № 5 (9). - Вип. 9. - Київ : Інститут психології імені Г. С. Костюка Національної академії педагогічних наук України, 2017. - С. $32-43$.

3. Блінов O. А. Опитувальник скринінгу посттравматичного стресового розладу (ОС ПТСР) / Психологічний часопис : збірник наукових праць / за ред. С. Д. Максименка. - № 1 (11). - Вип. 11. - Київ : Інститут психології імені Г. С. Костюка Національної академії педагогічних наук України, 2018. - С. 26-37.

4. Блінов О. А. Психологічний захист від бойового стресу в збройних силах провідних країн світу / Проблеми сучасної психології : Збірник наукових праць Кам'янець-Подільського національного університету імені Івана Огієнка, Інституту психології імені Г. С. Костюка НАПН України / за наук. ред. С. Д. Максименка, Л. А. Онуфрієвої. - Вип. 38. - Кам'янець-Подільський : Аксіома, 2017. - С. 38-52.

5. Военная психиатрия. Под ред. С. В. Литвинцева, В. К. Шамрея. - СПб. : ВМедА, ЭЛБИ-СПб., 2001. - С. 232.

6. Караяни А. Г. Настольная книга военного психолога : практич. пособие / А. Г. Караяни. - М. : Издательство Юрайт, 2016. - С. 77, 79. - Серия : Профессиональная практика.

7. Кравченко К. О., Тімченко О. В., Широбоков Ю. М. Соціально-психологічні детермінанти виникнення бойового стресу у військовослужбовців - учасників антитерористичної операції: монографія / К. О. Кравченко, О. В. Тімченко, Ю. М. Широбоков. - Харків.: НУЦЗУ, 
ФОЛ Мезіна В. В., 2017. - 186 с.

8. Кулагина И. Ю., Колюцкий В. Н. Возрастная психология: Полный жизненный цикл развития человека. Учебное пособие для студентов высших учебных заведений. - М. : ТЦ «Сфера», при участии «Юрайт-М», 2001. - С. 140.

9. Литвинцев С. В., Снедков Е. В., Резник А. М. Боевая психическая травма. - М. : Медицина, 2005. - С. 432.

10. Приходько I. I. Система профілактики та контролю бойового стресу у військовослужбовців / I. І. Приходько // Слайди виступу. Сучасний стан розвитку екстремальної та кризової психології: IV Міжнародна науково -практична конференція. - Х. : НУЦЗУ, 2017.

11. Друзь О. В. Донбасский синдром: 93\% участников АТО опасны для себя и общества / Виступ на круглому столі «Психологічна реабілітація та психіатрична допомога учасників антитерористичної операції. Шляхи зменшення суїцидів серед військовослужбовців та демобілізованих із зони АТО» засіданні комітету з охорони здоров'я Верховної Ради України 25 серпня 2017 року [Електронний ресурс]. - Режим доступу: https:// inforesist.org/glavnyiy-psihiatr-minoboronyi-93-atoshnikov -potentsialnaya-ugroza-dlya-obshhestva/

12. Лаад М. Многомерная модель внутренней устойчивости BASIC РН [Електронний ресурс]. - Режим доступу : http://stat.haifa.ac.il/ pavelg/downloads/ BASIC $\%$ 20PH.pdf

13. Blinov O. A. (2017). Psychological effects of combat stress. Fundamental and applied researches in practice of leading scientific schools, 20 (2). - P. 3-7.

14. Standard: NATO - STANAG 2409. Glossary of medical terms and definitions AMedP-13(A). Standardization agency (NSA) NATO. 6 May 2011. - P. 52.

15. Kardiner $A$. The traumatic Neurosis of War. N.Y.: Heber, 1941. - P. 86-89.

16. Kardiner A. Spiegel H. War Stress and Neurotic lines. N.Y., 1947. - P. 325-330.

\section{References (Transliteration):}

1. Blinov O. A. Psykhologhija bojovoji psykhichnoji travmy : monoghrafija / O. A. Blinov. - K. : Talkom, 2016. $-246 \mathrm{~s}$.

2. Blinov $O$. A. Opytuvaljnyk bojovogho stresu Blinova $\mathrm{O}$. A. (OBSB) / Psykhologhichnyj chasopys : zbirnyk naukovykh pracj / za red. S. D. Maksymenka. - \# 5 (9). Vyp. 9. - Kyjiv : Instytut psykhologhiji imeni Gh. S. Kostjuka Nacionaljnoji akademiji pedaghoghichnykh nauk Ukrajiny, 2017. - S. 32-43.

3. Blinov $O$. A. Opytuvaljnyk skryninghu posttravmatychnogho stresovogho rozladu (OS PTSR) / Psykhologhichnyj chasopys : zbirnyk naukovykh pracj / za red. S. D. Maksymenka. - \# 1 (11). - Vyp. 11. - Kyjiv : Instytut psykhologhiji imeni Gh. S. Kostjuka Nacionaljnoji akademiji pedaghoghichnykh nauk Ukrajiny, 2018. - S. 1934.

4. Blinov O. A. Psykhologhichnyj zakhyst vid bojovogho stresu v zbrojnykh sylakh providnykh krajin svitu / Problemy suchasnoji psykhologhiji : Zbirnyk naukovykh pracj Kam'janecj-Podiljsjkogho nacionaljnogho universytetu imeni Ivana Oghijenka, Instytutu psykhologhiji imeni Gh.S. Kostjuka NAPN Ukrajiny / za nauk. red. S. D. Maksymenka, L.A. Onufrijevoji. - Vyp. 38. - Kam'janecj-Podiljsjkyj : Aksioma, 2017. - S. 38-52. 5. Voennaia psikhiatriia. Pod red. S. V. Litvintseva, V. K. Shamreia. - SPb. : VMedA, ELBI-SPb., 2001. - S. 232.

6. Karaiani A. G. Nastolnaia kniga voennogo psikhologa : praktich. posobie / A. G. Karaiani. - M. : Izdatelstvo Iurait, 2016. - S. 77, 79. - Seriia : Professionalnaia praktika.

7. Kravchenko K. O., Timchenko O. V., Shyrobokov Ju. M. Socialjno-psykhologhichni determinanty vynyknennja bojovogho stresu u vijsjkovosluzhbovciv - uchasnykiv antyterorystychnoji operaciji: monoghrafija / K. O. Kravchenko, O. V. Timchenko, Ju. M. Shyrobokov. Kharkiv.: NUCZU, FOL Mezina V. V., 2017. - 186 s.

8. Kulagina I. Iu., Koliutskii V. N. Vozrastnaia psikhologiia: Polnyi zhiznennyi tsikl razvitiia cheloveka. Uchebnoe posobie dlia studentov vysshikh uchebnykh 
zavedenii. - M. : TTs «Sfera», pri uchastii «Iurait-M», 2001. - S. 140.

9. Litvintsev S. V., Snedkov E. V., Reznik A. M. Boevaia psikhicheskaia travma. - M. : Meditsina, 2005. - S. 432.

10. Prykhodjko I. I. Systema profilaktyky ta kontrolju bojovogho stresu u vijsjkovosluzhbovciv / I. I. Prykhodjko // Slajdy vystupu. Suchasnyj stan rozvytku ekstremaljnoji ta kryzovoji psykhologhiji: IV Mizhnarodna naukovo-praktychna konferencija. - Kh. : NUCZU, 2017.

11. Druzj O. V. Donbasskii sindrom: 93\% uchastnikov ATO opasny dlia sebia i obshchestva / Vystup na krughlomu stoli «Psykhologhichna reabilitacija ta psykhiatrychna dopomogha uchasnykiv antyterorystychnoji operaciji. Shljakhy zmenshennja sujicydiv sered vijsjkovosluzhbovciv ta demobilizovanykh iz zony ATO» zasidanni komitetu z okhorony zdorov'ja Verkhovnoji Rady Ukrajiny 25 serpnja 2017 roku [Elektronnyj resurs]. Rezhym dostupu: https://inforesist.org/glavnyiy-psihiatrminoboronyi-93-atoshnikov-potentsialnaya-ugroza-dlyaobshhestva/

12. Laad M. Mnogomernaia model vnutrennei ustoichivosti BASIC PH [Elektronnii resurs]. - Rezhim dostupu : http:// stat.haifa.ac.il/ pavelg/downloads/ BASIC\%20PH.pdf

13. Blinov O. A. (2017). Psychological effects of combat stress. Fundamental and applied researches in practice of leading scientific schools, 20 (2). - S. 3-7.

14. Standard: NATO - STANAG 2409. Glossary of medical terms and definitions AMedP-13(A). Standardization agency (NSA) NATO. 6 May 2011. S. 52.

15. Kardiner A. The traumatic Neurosis of War. N.Y.: Heber, 1941. - S. 86-89.

16. Kardiner A. Spiegel H. War Stress and Neurotic lines. N.Y., 1947. - S. 325-330.

\section{Oleg Blinov}

PhD in Psychology, Associate Professor, Scientific Correspondent of I. O. Sinitsy Laboratory of Educational Psychology, H. S. Kostyuk Institute of Psychology of the National Academy of Educational Sciences of Ukraine, Kyiv (Ukraine)

\section{COMBAT STRESS AND RESULTS OF ITS EMPIRICAL STUDY}

\section{ABSTRACT}

The article deals with the phenomenology of combat stress and the conditions for its emergence. The actuality of the problem of combat stress and post-traumatic stress disorder of military men is shown. The analysis of opinions of experts about the features and possible levels of its manifestations has been carried out. The results of research on combat stress and posttraumatic stress disorder are presented. The reasons and peculiarities of the manifestations of the emotional experiences of military men as a result of traumatic stress are defined and considered with the help of the posttraumatic stress disorder screening questionnaire (PTSD SQ), the questionnaire of combat stress by O. A. Blinov (CSQ). The correlation relationships between the indicators of combat stress of the questionnaires were established.

As a result of empirical studies, it has been determined that $8 \%$ of military men who participated in combat operations need an indepth examination of the probability of posttraumatic stress disorder, and it was detected in $19 \%$ of them. Among the wounded combatants $13 \%$ require additional examination on the sub- 
ject of post-traumatic stress disorder, and it was detected in $46 \%$ of military men.

Key words: military men, combat stress, post-traumatic stress disorder, injury, contusions.

\section{Блинов Олег}

Кандидат психологических наук, дочент, доиент кафедры социальных технологий Национального авиационного университета, научный корреспондент лаборатории психологии обучения имени И. О. Синиць Института психологии имени Г. С. Костюка Национальной академии педагогических наук Украины, г. Киев (Украина)

\section{БОЕВОЙ СТРЕСС И РЕЗУЛЬТАТЫ ЕГО ЭМПИРИЧЕСКОГО ИССЛЕДОВАНИЯ}

Аннотация. В статье рассматривается феноменология боевого стресса и условия его возникновения. Осуществлена характеристика боевого стресса и приведены последствия его действия. Проведен исторический обзор научных подходов изучения категории «боевой стресс». Представлены результаты эмпирического исследования боевого стресса и посттравматического стрессового расстройства. Проанализирована динамика показателей боевого стресса в зависимости от срока пребывания в зоне боевых действий. Определены причины и рассмотрены особенности проявлений переживаний военнослужащих в результате действия травматического стресса с помощью опросника скрининга посттравматического стрессового расстройства (ОС ПТСР) и опросника боевого стресса Блинова О. А. (ОБСБ).
Рассмотрены корреляционные связи между показателями боевого стресса опросников.

В результате эмпирических исследований было установлено, что у $8 \%$ военнослужащих, которые принимали участие в боевых действиях, присутствуют неполные клинические проявления ПТСР, также их вероятность установлена у 19\% бойцов. Неполные клинические проявления ПТСР имеют 13\% раненных, также вероятность ПТСР установлена у $46 \%$ раненных бойцов.

Ключевые слова: военнослужащие, боевой стресс, посттравматическое стрессовое расстройство, ранения, контузии. 